\title{
In Situ Conservation of America's Wild Grapes
}

\author{
Diane S. Pavek \\ U.S. Department of Agriculture, Agriculture Research Service, National Germplasm Resources Laboratory, Plant \\ Exchange Office, 10300 Baltimore Ave., Beltsville, MD 20705-2350
}

Warren F. Lamboy

U.S. Department of Agriculture, Agriculture Research Service, Plant Genetic Resources Unit, Cornell University, Geneva, NY 14456-0462

\author{
Edward J. Garvey \\ U.S. Department of Agriculture, Agriculture Research Service, National Germplasm Resources Laboratory, Plant \\ Exchange Office, 10300 Baltimore Ave., Beltsville, MD 20705-2350
}

\begin{abstract}
Characterizing genetic diversity and its distribution throughout species' ranges furthers our understanding about the adaptation and survival of wild species and ensures that genetic resources are available for study or potential use in research and breeding programs. Both in situ (i.e., preserving wild populations in their natural habitats) and ex situ approaches are important to the conservation of genetic resources (Bretting and Duvick, 1997; Dulloo et al., 1998; Merezhko, 1998; Nevo, 1998). Most of our staple crops are native to other continents, which means that in situ conservation of wild crop relatives in America will have a limited role in the U.S. Dept. of AgricultureAgricultural Research Service (USDA-ARS) National Plant Germplasm System (NPGS). However, for wild crop relatives native to the United States, in situ conservation is desirable, since the populations would continue to be exposed to coevolution (host-pest/ pathogen), natural selection (environmental and biotic stresses), and other pressures (mutation, gene flow, and genetic drift) that are the keys to changing adaptations and diversities. The resulting genetic diversity in these populations of wild crop relatives is an underutilized reservoir of potentially novel resistances and tolerances (Burdon and Jarosz, 1989; Maxted et al., 1997; Zencirci et al. 1998). In situ conservation can complement the existing ex situ collections in the NPGS.
\end{abstract}

The crop curator is the essential link in the NPGS between evolutionary conservation and utilization. In establishing in situ conservation programs, the curator will screen wild populations for genetic distinction throughout a species' range, prioritize the sampled populations as candidates for in situ conservation, arrange conservation agreements with landowners, and make the germplasm available to researchers and breeders. Where appropriate, curators need to implement in situ programs because the risk of losing native genetic resources increases with the habitat loss, land conversion, and changes in land use occurring across America (Waller, 1996).

We undertook a 2-year project to examine the feasibility of establishing in situ conservation sites for three grape (Vitis L.) species native to the United States. The initial phase focused on rock grape

Received for publication 22 May 2000. Accepted for publication 13 June 2000. We are grateful to Joseph Kirkbride, U.S. Dept. of Agriculture, Seed Herbarium, for requesting the following loans for study and to the staff members of the following herbaria for access to specimens (using standard herbarium abbreviations): TEX, TAMU, CM, FM, FLAS, BH, US, NA, NLU, UNM, GA MO, and NY. We thank the Endangered Resources Branch of Texas Parks and Wildlife for location and status information. We appreciate information and access to grape populations given by the staff members from the Merritt Island Wildlife Refuge, Fla.; Jonathan Dickinson, Myakka River, and Hillsborough River State Parks, Fla.; and Garner, Guadelupe River, Pedernales River State Parks and the Hill Country State Natural Area, Texas. We thank Cui Tiecheng from Xian Botanical Garden, China, and John Asbury, Temple, Texas, for field assistance; and Paul Schmalzer, Dynamac Corp., Kennedy Space Center, Fla. for sharing his field observations in Florida. The comments of two anonymous reviewers and Stan Hokanson made this a better paper. We are grateful to the late Michael Moore, who allowed us access to his Vitaceae treatment in manuscript form and for very helpful taxonomic discussions. The cost of publishing this paper was defrayed in part by the payment of page charges. Under postal regulations, this paper therefore must be hereby marked advertisement solely to indicate this fact.
(Vitis rupestris Scheele), a species of concern to conservationists because of extensive habitat loss. Out of seven rock grape populations proposed as in situ conservation sites, four were finally established as the first such conservation sites within the NPGS. In the final year of the project, work focused on populations of Caloosa grape (Vitis shuttleworthii House), an endemic to central and southern Florida, and sweet mountain grape (Vitis monticola Buckl.), an endemic on the Edwards Plateau in central Texas.

Caloosa and sweet mountain grapes are important to agriculture for breeding potential, but are not state-listed conservation concerns. Caloosa grape is reported as being resistant to Pierce's disease (Xylella fastidiosa Wells et al.), a virulent disease that prevents Vitis vinifera $\mathrm{L}$. (i.e., the commercial wine and table grape species) from being grown in the southeastern United States (Banks et al., 1999; Loomis, 1958; Reisch and Pratt, 1996). However, in the vineyard setting, the wild Caloosa grape may express differential susceptibility to Pierce's disease (J. Grinstead, Meramec and Vinewood Vitis Vineyards, Rolla, Mo., pers. comm., 1998). Caloosa grape has a globally threatened conservation status of vulnerable (Walter and Gillett, 1998). Currently, the state of Florida does not monitor this species (B. Lenczewski, Environmental Reviewer, Florida Natural Areas Inventory, Tallahassee, Fla., pers. comm., 1997).

Although difficult to propagate, sweet mountain grape is tolerant to calcareous soils and to grape phylloxera (Daktulosphaira vitifoliae Fitch) and other diseases (Mullins et al., 1992; Reisch and Pratt, 1996; Wapshere and Helm, 1987). Sweet mountain grape is not currently a species of concern in Texas (D. Scott, Texas Biol. and Conserv. Data System, Austin, Texas, pers. comm., 1998). Both of these species are vulnerable to grazing and often occur only in fencerows where they escape herbivory. Additionally, frequent prescribed or recurrent burns (every 3 to 4 years) will eliminate Caloosa grape (herbarium specimens and personal observation, 1998). The objective of this study was to use molecular and morphological data to characterize populations throughout their ranges and propose in situ conservation sites, following a strategy initially used for rock grape populations.

\section{ESTABLISHING IN SITU CONSERVATION SITES}

Information on species' geographic distribution, ecological requirements, and phenology was necessary before beginning field sampling. Accurately identified herbarium sheets were examined from 13 herbaria for location information and morphologic measurements. Taxonomic identifications were based on Moore's treatment (1991; pers. comm., 1997).

Historical locations were examined, and morphological measurements, DNA samples, and voucher specimens were collected (Fig. 1). Up to 30 plants were randomly selected from each population to examine genetic differentiation. Three leaves from each genet (i.e., nonclonal individual plant) were collected and preserved with silica gel for later DNA extraction (Chase and Hills, 1991; Wang et al., 1996).

In the laboratory, genomic DNA samples were screened with four simple sequence repeat (SSR) primer pairs (VVS2, VVS4, VVMD6, and VVMD7) following previously described methods (Lamboy and Alpha, 1998). The data from each SSR locus were summarized for 


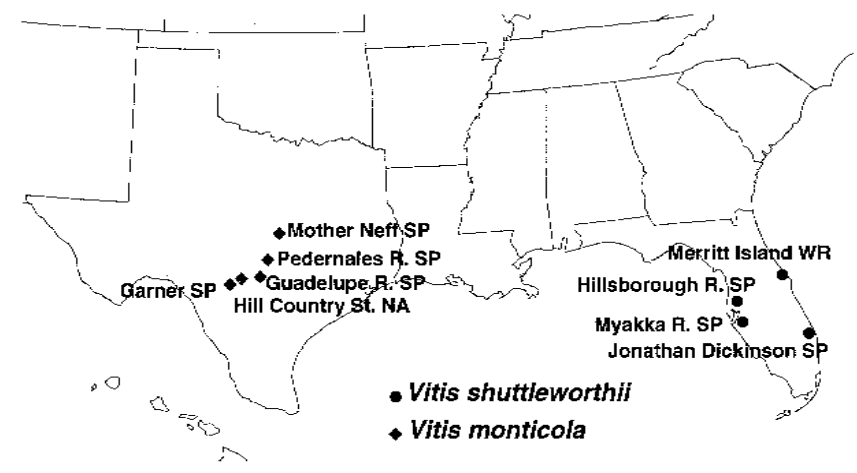

Fig. 1. Locations of collection sites proposed as in situ conservation sites for Vitis shuttleworthii and V. monticola. Merritt Island Wildlife Refuge (administered by the U.S. Dept. of Interior); Jonathan Dickinson, Myakka River, and Hillsborough River State Parks in Florida (all administered by the Florida Dept. of Environmental Protection); and Guadelupe River and Mother Neff State Parks and the Hill Country State Natural Area in Texas (all administered by Texas Parks and Wildlife).

each population by four measures of genetic variation: number of alleles and genotypes per locus, percent heterozygous plants per locus, and polymorphic information content (PIC), which is the1-sum of the squares of all gene frequencies at a locus. Over all loci, the average heterozygosity and average PIC were calculated for each population alone and for all populations together.

Morphological characters, important to breeding and germplasm management, were measured on the clones of genets within populations. The continuous data (leaf length and width, petiole length, berry and bunch lengths and widths) were analyzed by multivariate analysis of variance (MANOVA), with the factors population and genet nested within population (SAS Institute Inc., 1997, PROC GLM). When significant differences in morphological traits were detected with MANOVA, posthoc analysis of variance (ANOVA) and multiple comparison tests were performed (SAS Institute Inc., 1997, PROC GLM). Chi-square tests using Fisher's exact tests were used to analyze the discrete data (leaf shape, leaf teeth shape, leaf sinus shape and width, leaf margin pubescence, tendril persistence, number of successive nodes with tendrils) (CYTEL Software Corp., 1996).

\section{RESULTS AND DISCUSSION}

Morphological analysis. All morphological and molecular analyses were run separately for each species. The MANOVAs for the continuous variables indicated that morphological variation among and within the four populations of Caloosa grape and the five populations of sweet mountain grape were significant or highly significant (Table 1). Subsequent ANOVA tests indicated significant differences for three variables: leaf length and width and petiole length (Table 2). The means for 1) all four Caloosa grape populations and 2) three of the five sweet mountain grape populations (Guadelupe River State Park (S.P.), Hill Country State Natural Area (N.A.), and Mother Neff S.P., Texas) differed significantly (Table 3 ). Fisher's exact test revealed significant differences for four discrete characters (leaf teeth shape, sinus width and shape, and gender) among the Caloosa grape populations and for three characters (leaf teeth shape, sinus width, and gender) among the sweet mountain grape populations (Table 4). Although morphology is determined by both genetic and environmental factors, the morphological analyses suggested that in situ conservation sites might be needed for all four Caloosa grape populations and for the three sweet mountain grape populations mentioned above.

Molecular analysis. The total number of different alleles for the four SSR loci ranged from one VVMD7 allele to nine VVS2 alleles for Caloosa grape and from one VVMD6 allele to 10 VVMD7 alleles for sweet mountain grape. (A summary of all alleles by populations is available upon request.) Levels of heterozygosity per locus averaged $21 \%$ for Caloosa grape populations, with a range from $0 \%$ to $71 \%$, and an average of $53 \%$ for sweet mountain grape populations, with a range
Table 1. Multivariate analysis of variance complete (leaf length and width, petiole length, bunch number, length, and width, and berry number, length, and width) and partial (leaf length and width, petiole length; no fruit characters) models for morphological characters for Vitis shuttleworthii and $V$. monticola populations.

\begin{tabular}{|c|c|c|c|c|c|c|}
\hline Model & $\mathrm{N}$ & $\begin{array}{l}\text { Wilks' } \\
\text { Source }\end{array}$ & Lambda & $\begin{array}{c}\mathrm{Num}^{2} \\
\mathrm{df}\end{array}$ & F-value & $P$ \\
\hline \multicolumn{7}{|c|}{ Vitis shuttleworthii } \\
\hline \multirow[t]{2}{*}{ Complete } & 87 & Population & 0.1697 & 27 & 4.54 & 0.0001 \\
\hline & & Genet(Pop) & 0.0 & 225 & 1.54 & 0.0001 \\
\hline \multirow[t]{2}{*}{ Partial } & 317 & Population & 0.4009 & 9 & 25.77 & 0.0001 \\
\hline & & Genet(Pop) & 0.0723 & 306 & 2.87 & 0.0001 \\
\hline \multicolumn{7}{|c|}{ Vitis monticola } \\
\hline \multirow[t]{2}{*}{ Complete } & 75 & Population & 0.3259 & 36 & 1.54 & 0.0374 \\
\hline & & Genet(Pop) & 0.0116 & 180 & 1.45 & 0.0016 \\
\hline \multirow[t]{2}{*}{ Partial } & 186 & Population & 0.5821 & 12 & 6.11 & 0.0001 \\
\hline & & Genet(Pop) & 0.1547 & 171 & 1.85 & 0.0001 \\
\hline
\end{tabular}

${ }^{2} \mathrm{Num} \mathrm{df}=$ numerator degrees of freedom.

Table 2. ANOVA for morphological characters (leaf length and width, petiole length) for Vitis shuttleworthii and V. monticola.

\begin{tabular}{|c|c|c|c|c|c|}
\hline Character & Source & $\begin{array}{c}\mathrm{Num}^{2} \\
\mathrm{df}\end{array}$ & $\begin{array}{c}\operatorname{Den}^{2} \\
\text { df }\end{array}$ & F-value & $P$ \\
\hline \multicolumn{6}{|c|}{ Vitis shuttleworthii } \\
\hline \multirow[t]{2}{*}{ Leaf length } & Population & 3 & 102 & 11.24 & 0.0001 \\
\hline & Genet(Pop) & 102 & 211 & 4.39 & 0.0001 \\
\hline \multirow[t]{2}{*}{ Leaf width } & Population & 3 & 102 & 16.07 & 0.0001 \\
\hline & Genet(Pop) & 102 & 211 & 4.88 & 0.0001 \\
\hline \multirow[t]{2}{*}{ Petiole length } & Population & 3 & 102 & 16.87 & 0.0001 \\
\hline & Genet(Pop) & 102 & 211 & 3.25 & 0.0001 \\
\hline \multicolumn{6}{|c|}{ Vitis monticola } \\
\hline \multirow[t]{2}{*}{ Leaf length } & Population & 4 & 57 & 6.19 & 0.0003 \\
\hline & Genet(Pop) & 57 & 124 & 1.85 & 0.0024 \\
\hline \multirow[t]{2}{*}{ Leaf width } & Population & 4 & 57 & 5.56 & 0.0007 \\
\hline & Genet(Pop) & 57 & 124 & 1.77 & 0.0044 \\
\hline \multirow[t]{2}{*}{ Petiole length } & Population & 4 & 57 & 5.35 & 0.0010 \\
\hline & Genet(Pop) & 57 & 124 & 2.55 & 0.0001 \\
\hline
\end{tabular}

${ }^{{ }^{2} \mathrm{Num}} \mathrm{df}=$ numerator degrees of freedom; Den $\mathrm{df}=$ denominator degrees of freedom.

Table 3. Multiple comparisons for all three continuous characters (leaf length and width and petiole length) comparing means with $t$ test.

\begin{tabular}{lcccc}
\hline \hline Population $^{z}$ & $\mathrm{~N}$ & $\begin{array}{c}\text { Leaf length } \\
(\mathrm{cm})\end{array}$ & $\begin{array}{c}\text { Leaf width } \\
(\mathrm{cm})\end{array}$ & $\begin{array}{c}\text { Petiole } \\
(\mathrm{cm})\end{array}$ \\
\hline \multicolumn{5}{c}{ Vitis shuttleworthii } \\
Merritt Isl. W.R. & 68 & $7.38 \mathrm{a}^{\mathrm{y}}$ & $9.34 \mathrm{a}$ & $4.58 \mathrm{a}$ \\
Jonathan Dickinson S.P. & 69 & $5.58 \mathrm{~d}$ & $6.69 \mathrm{~d}$ & $2.85 \mathrm{~d}$ \\
Myakka R. S.P. & 90 & $6.02 \mathrm{c}$ & $7.47 \mathrm{c}$ & $3.39 \mathrm{c}$ \\
Hillsborough R. S.P. & 90 & $6.48 \mathrm{~b}$ & $9.34 \mathrm{~b}$ & $4.13 \mathrm{~b}$ \\
& Vitis monticola & & \\
Garner S.P. & 30 & $7.20 \mathrm{ab}$ & $7.62 \mathrm{ab}$ & $2.90 \mathrm{bc}$ \\
Guadelupe R. S.P. & 33 & $7.09 \mathrm{ab}$ & $8.05 \mathrm{a}$ & $3.33 \mathrm{ab}$ \\
Hill Country S.N.A. & 48 & $6.53 \mathrm{bc}$ & $7.23 \mathrm{bc}$ & $2.90 \mathrm{cb}$ \\
Pedernales Falls S.P. & 30 & $5.89 \mathrm{c}$ & $6.80 \mathrm{c}$ & $2.57 \mathrm{c}$ \\
Mother Neff S.P. & 45 & $7.47 \mathrm{a}$ & $8.35 \mathrm{a}$ & $3.59 \mathrm{a}$ \\
\hline
\end{tabular}

${ }^{2}$ W.R. = Wildlife Refuge; S.P. $=$ State Park; R. = River; S.N.A. = State Natural Area.

${ }^{\mathrm{y}}$ Mean separation within species and columns by $t$ test, $P \leq 0.05$.

Table 4. Fisher's exact tests for discrete morphological characters of two Vitis species.

\begin{tabular}{|c|c|c|c|c|c|c|}
\hline Character & $\mathrm{df}$ & Value & $P$ & $\mathrm{df}$ & Value & $P$ \\
\hline & \multicolumn{3}{|c|}{--- Vitis shuttleworthii ----. } & \multicolumn{3}{|c|}{--- Vitis monticola } \\
\hline Leaf shape & 9 & 11.58 & 0.0608 & 4 & 3.03 & 0.6961 \\
\hline Tooth shape & 6 & 65.75 & $0.00001^{*}$ & 4 & 23.48 & $0.0028^{*}$ \\
\hline Sinus & 9 & 74.49 & $0.00001^{*}$ & 12 & 21.60 & $0.0038^{*}$ \\
\hline Sinus & 9 & 40.54 & $0.00001^{*}$ & 4 & 4.33 & 0.3518 \\
\hline Gender & 6 & 46.64 & $0.00001^{*}$ & 8 & 13.40 & $0.0329^{*}$ \\
\hline No. of nodes & 6 & 8.01 & 0.2200 & & & \\
\hline
\end{tabular}

${ }^{*}$ Significant test under a sequential Bonferroni. 
Table 5. Summary of genetic diversity measurements at four SSR loci (VVS2, VVS4, VVMD6, VVMD7) for four Vitis shuttleworthii and five V. monticola populations.

\begin{tabular}{|c|c|c|c|c|c|c|c|c|c|c|c|c|c|c|c|c|c|c|c|c|}
\hline \multirow[b]{2}{*}{ Population $^{2}$} & \multicolumn{5}{|c|}{ VVS2 } & \multicolumn{5}{|c|}{ VVS4 } & \multicolumn{5}{|c|}{ VVMD6 } & \multicolumn{5}{|c|}{ VVMD7 } \\
\hline & $\mathrm{N}^{\mathrm{y}}$ & $\mathrm{A}$ & $\mathrm{G}$ & $\mathrm{H}$ & $\mathrm{PIC}$ & $\mathrm{N}$ & $\mathrm{A}$ & $\mathrm{G}$ & $\mathrm{H}$ & $\mathrm{PIC}$ & $\mathrm{N}$ & $\mathrm{A}$ & $\mathrm{G}$ & $\mathrm{H}$ & $\mathrm{PIC}$ & $\mathrm{N}$ & $\mathrm{A}$ & $\mathrm{G}$ & $\mathrm{H}$ & $\mathrm{PIC}$ \\
\hline \multicolumn{21}{|c|}{ Vitis shuttleworthii } \\
\hline Merritt Isl. W.R. & 21 & 6 & 8 & 71 & 0.68 & 11 & 3 & 3 & 18 & 0.31 & 21 & 2 & 2 & 0 & 0.09 & 21 & 3 & 4 & 14 & 0.21 \\
\hline Myakka R. S.P. & 27 & 6 & 8 & 63 & 0.63 & 13 & 4 & 4 & 39 & 0.59 & 27 & 2 & 2 & 0 & 0.07 & 26 & 1 & 1 & 0 & 0.00 \\
\hline Hillsborough R. S.P. & 26 & 9 & 9 & 35 & 0.73 & 15 & 6 & 6 & 20 & 0.63 & 28 & 2 & 2 & 0 & 0.69 & 28 & 2 & 3 & 4 & 0.10 \\
\hline \multicolumn{21}{|c|}{ Vitis monticola } \\
\hline Hill Country S.N.A. & 9 & 4 & 4 & 67 & 0.62 & 6 & 6 & 6 & 83 & 0.78 & 6 & 4 & 5 & 33 & 0.69 & 7 & 8 & 7 & 100 & 0.84 \\
\hline Pedernales Falls S.P. & 10 & 4 & 3 & 20 & 0.27 & 7 & 8 & 7 & 43 & 0.85 & 9 & 4 & 5 & 33 & 0.67 & 9 & 8 & 7 & 89 & 0.81 \\
\hline Mother Neff S.P. & 13 & 3 & 3 & 15 & 0.15 & 11 & 7 & 8 & 91 & 0.80 & 12 & 5 & 6 & 25 & 0.66 & 12 & 10 & 9 & 58 & 0.80 \\
\hline
\end{tabular}

${ }^{2}$ W.R. = Wildlife Refuge; S.P. = State Park; R. = River; S.N.A. = State Natural Area.

${ }^{y} \mathrm{~N}=$ number of plants; $\mathrm{A}=$ number of alleles; $\mathrm{G}=$ number of genotypes; $\mathrm{H}=$ percent heterozygous plants; $\mathrm{PIC}=$ polymorphic information content.

of $0 \%$ to $100 \%$ (Tables 5 and 6). Average gene diversity or PIC values varied from an average of 0.34 for Caloosa grape populations (ranging from 0 to 0.73 ) to an average of 0.64 for sweet mountain grape populations (ranging from 0 to 0.85 ). All Caloosa grape populations and four sweet mountain grape populations had alleles unique to this study. Three Caloosa grape populations (Merritt Island Wildlife Refuge, Hillsborough R. S.P., and Jonathan Dickinson S.P.) each contained four unique alleles (Table 7). Two sweet mountain grape populations (Guadelupe R. S.P. and Mother Neff S.P.) each contained six or more unique alleles. The unique alleles reflected geographically localized, non-overlapping genetic differences, which should be included when selecting populations to conserve (Schoen and Brown, 1993).

These two endemic grape species have different amounts of genetic diversity at these SSR loci. Rock grape that was evaluated in the first phase of our in situ conservation work was not an endemic; its range extended from Pennsylvania to Texas. Average heterozygosity across all loci and populations for rock grape was $45 \%$ with the average PIC of 0.53 , which were similar to sweet mountain grape values (Pavek et al., unpublished). However, Caloosa grape had lower amounts of genetic diversity than did either the endemic sweet mountain grape or the widespread rock grape.

In an SSR study of 25 cultivars and wild species from the NPGS grape genetic resources collection, heterozygosity ranged from 0.46 to 0.82 with a mean of 0.63 , and the PIC values were substantially higher, ranging from 0.88 to 0.96 , with an average of 0.91 (Lamboy and Alpha, 1998). Because the grape genetic resources collection holds a broad array of species and genotypes, that the study of 25 taxa yielded higher heterozygosity and PIC values than our study of only two taxa is not surprising.

Strategy for proposing preserves. The following criteria were used to designate potential populations of interest for establishing in situ

Table 6. Average heterozygosity and polymorphic information content for each species and population of Vitis.

\begin{tabular}{lccc}
\hline \hline Population $^{z}$ & $\mathrm{~N}^{\mathrm{y}}$ & Avg H & Avg PIC \\
\hline & \multicolumn{3}{c}{ Vitis shuttleworthii } \\
Merritt Isl. W.R. & 21 & 26 & 0.33 \\
Jonathan Dickinson S.P. & 20 & 16 & 0.34 \\
Myakka R. S.P. & 27 & 25 & 0.32 \\
Hillsborough R. S.P. & 28 & 15 & 0.38 \\
\multicolumn{1}{c}{ All populations } & 96 & 21 & 0.34 \\
& & Vitis monticola & \\
Garner S.P. & 5 & 45 & 0.47 \\
Guadelupe R. S.P. & 13 & 55 & 0.77 \\
Hill Country S.N.A. & 9 & 71 & 0.73 \\
Pedernales Falls S.P. & 10 & 46 & 0.65 \\
Mother Neff S.P. & 13 & 47 & 0.60 \\
$\quad$ All populations & 50 & 53 & 0.64 \\
\hline
\end{tabular}

${ }^{2}$ W.R. $=$ Wildlife Refuge; S.P. $=$ State Park; R. = River; S.N.A. $=$ State Natural Area.

${ }^{y} \mathrm{~N}=$ number of plants; $\mathrm{H}=$ percent heterozygous plants; $\mathrm{PIC}=$ polymorphic information content. conservation sites. We began with molecular markers and applied subsequent categories.

1) Molecular markers. Our goal was to preserve the maximum genetic diversity across the range of sweet mountain and Caloosa grapes. First, we chose the population with the largest number of alleles and genotypes, which was Hillsborough River S.P. for Caloosa grape, with 19 alleles and 20 genotypes, and Guadelupe River S.P. for sweet mountain grape, with 25 alleles and 28 genotypes. Second, we included populations that had alleles unique to this study. Each of the four Caloosa grape populations had unique alleles. Only one (Garner S.P.) of the five sweet mountain grape populations had no unique alleles and was excluded.

2) Morphology. We compared these eight, genetically distinct populations (four each of Caloosa grape and sweet mountain grape populations) with populations that were significantly different for morphological characters. All populations of Caloosa grape were significantly different from one another. For the remaining four sweet mountain grape populations, only three, Guadelupe River S.P., Hill Country State N.A., and Mother Neff S.P., had significant morphological differences.

3) Population size. The numbers of individuals within a population had to be sufficient to avoid the consequences of demographic stochasticity; i.e., actual number of different breeding pairs and wide swings in births and deaths. All populations of both species were locally abundant and sufficiently large.

Table 7. SSR alleles unique to Vitis shuttleworthii or Vitis monticola populations.

\begin{tabular}{|c|c|c|c|c|}
\hline \multirow[b]{2}{*}{ Locus } & \multicolumn{2}{|r|}{ Vitis shuttleworthii } & \multicolumn{2}{|c|}{ Vitis monticola } \\
\hline & Allele & Population $^{2}$ & Allele & Population \\
\hline \multirow[t]{5}{*}{ VVS2 } & 129 & Merritt Island W.R. & 125 & $\overline{\text { Hill Country S.N.A. }}$ \\
\hline & 140 & Myakka R. & 134 & Guadelupe R. S.P. \\
\hline & 144 & Hillsborough R. S.P. & & \\
\hline & 149 & Hillsborough R. S.P. & & \\
\hline & 150 & Jonathan Dickinson S.P. & & \\
\hline \multirow[t]{4}{*}{ VVS4 } & 181 & Merritt Island W.R. & 175 & Mother Neff S.P. \\
\hline & 186 & Hillsborough R. S.P. & 186 & Guadelupe R. S.P. \\
\hline & 193 & Jonathan Dickinson S.P. & 191 & Mother Neff S.P. \\
\hline & 195 & Hillsborough R. S.P. & & \\
\hline \multirow[t]{7}{*}{ VVMD6 } & 210 & Jonathan Dickinson S.P. & 205 & Mother Neff S.P. \\
\hline & & & 206 & Hill Country S.N.A. \\
\hline & & & 207 & Mother Neff S.P. \\
\hline & & & 210 & Guadelupe R. S.P. \\
\hline & & & 211 & Pedernales Falls S.P. \\
\hline & & & 213 & Guadelupe R. S.P. \\
\hline & & & 216 & Pedernales Falls S.P. \\
\hline \multirow[t]{6}{*}{ VVMD7 } & 238 & Merritt Island W.R. & 236 & Guadelupe R. S.P. \\
\hline & 244 & Merritt Island W.R. & 240 & Mother Neff S.P. \\
\hline & 247 & Jonathan Dickinson S.P. & 242 & Guadelupe R. S.P. \\
\hline & 249 & Hill Country S.N.A. & & \\
\hline & 259 & Mother Neff S.P. & & \\
\hline & 264 & Mother Neff S.P. & & \\
\hline
\end{tabular}

${ }^{2}$ W.R. $=$ Wildlife Refuge; S.P. $=$ State Park; R. = River; S.N.A. = State Natural Area. 
4) Population integrity. The genetic integrity of the Caloosa or sweet mountain grape populations selected was not threatened by or compromised by human intervention through active movement of genets. All previously selected populations met this criterion.

5) Landholder. From our final list of proposed populations, the exclusion of populations from in situ preservation will occur if the landholding agency refuses to enter into a cooperative agreement. All proposed populations were on public lands; no lands needed to be purchased or conservation easements needed to be sought. We submitted cooperative agreements to the landholding agencies for their consideration. Land managers were asked to manage these populations by avoiding disruption or degradation of the habitats and ecosystems in which they occur.

These in situ conservation sites complement existing ex situ grape collections and do not replace them. Open-pollinated seed or budwood collected from the wild is held in the medium-term storage facilities of the NPGS repository in Geneva, N.Y. for distribution. In addition, seeds will be maintained at the USDA National Seed Storage Lab, Fort Collins, Colo., for long-term, back-up preservation. When needed, fresh propagules will be recollected from the in situ site instead of regenerating them at the repository.

\section{PROPOSED IN SITU CONSERVATION SITES}

The characterization of inter- and intra-population genetic variation by molecular and morphological methods determined which populations of Caloosa grape and sweet mountain grape were significant genetic resources. Not all populations of a species were necessarily designated as in situ conservation sites. Based on unique alleles or combinations of genotypes and significant morphological differences, we proposed four populations of Caloosa grape and three populations of sweet mountain grape as in situ conservation sites. The conservation management of these wild crop relatives is based on voluntary cooperation between NGRL and federal and state agencies. The curator will take effective action by monitoring populations annually, observing the specified conditions of the agreement, and distributing germplasm. These first NPGS in situ conservation sites preserve significant populations of rock, Caloosa, and sweet mountain grape.

\section{Literature Cited}

Banks, D., R. Albibi, J. Chen, O. Lamikanra, R. Jarret, and B. Smith. 1999. Specific detection of Xylella fastidiosa Pierce's disease strains. Curr. Microbiol. 39:85-88.

Bretting, P.K. and D.N. Duvick. 1997. Dynamic conservation of plant genetic resources. Adv. Agron. 61:1-51.

Burdon, J.J. and A.M. Jarosz. 1989. Wild relatives as sources of disease resistance, p. 289-296. In: A.H.D. Brown, O.H. Frankel, D.R. Marshall, and J.T. Williams (eds.). The use of plant genetic resources. Cambridge Univ. Press, Cambridge, U.K.

Chase, M.W. and H.H. Hills. 1991. Silica gel: An ideal material for field preservation of leaf samples for DNA studies. Taxon 40:215-220.

CYTEL Software Corp. 1996. StatXact-3 for Windows. CYTEL Software Corp., Cambridge, Mass.

Dulloo, M.E., L. Guarino, F. Engelmann, N. Maxted, J.H. Newbury, F. Attere, and B.V. Ford-Lloyd. 1998. Complementary conservation strategies for the genus Coffea: A case study of Mascarene Coffea species. Genet. Res. Crop Evol. 45:565-579.

Lamboy, W.F. and C.G. Alpha. 1998. Using simple sequence repeats (SSRs) for DNA fingerprinting germplasm accessions of grape (Vitis L.) species. J. Amer. Soc. Hort. Sci. 123:182-188.

Loomis, H.H. 1958. Performance of Vitis species in the South as an indication of their relative resistance to Pierce's disease. Plant Dis. Rptr. 42:833-836.

Maxted, N., B.V. Ford-Lloyd, and J.G. Hawkes (eds.). 1997. Plant genetic conservation: The in situ approach. Chapman and Hall, New York.

Merezhko, A.F. 1998. In situ and ex situ conservation of plant genetic diversity are links of a common back-up system, p. 49-53. In: N. Zencirci, Z. Kaya, Y. Anikster, and W.T. Adams (eds.). Proc. Intl. Symp. on In Situ Conservation of Plant Genetic Diversity. Central Res. Inst. for Field Crops, Ankara, Turkey.

Moore, M.O. 1991. Classification and systematics of eastern North American Vitis L. (Vitaceae) north of Mexico. Sida 14:339-367.

Mullins, M.G., A. Bouquet, and L.E. Williams. 1992. Biology of the grapevine. Cambridge Univ. Press, Cambridge, U.K.

Nevo, E. 1998. Genetic diversity in wild cereals: Regional and local studies and their bearing on conservation ex situ and in situ. Genet. Res. Crop Evol. 45:355-370.

Reisch, B. and C. Pratt. 1996. Grapes, p. 297-369. In: J. Janick and J.N. Moore (eds.). Fruit breeding, Vol. II: Vine and small fruits crops. Wiley, New York.

SAS Institute Inc. 1997. SAS/STAT software: Changes and enhancements through Release 6.12. SAS Inst., Cary, N.C.

Schoen, D.J. and A.H.D. Brown. 1993. Conservation of allelic richness in wild crop relatives is aided by assessment of genetic markers. Proc. Natl. Acad. Sci., U.S.A. 90:10623-10627.

Waller, D.A. 1996. Biodiversity as a basis for conservation efforts, p. 16-32. In: W.J. Snape, III (ed.). Biodiversity and the law. Island Press, Washington, D.C.

Walter, K.S. and H.J. Gillett (eds.). 1998. 1997 IUCN red list of threatened plants. IUCN-The World Conservation Union, Gland, Switzerland, IUCN Publ. Unit, Cambridge, U.K.

Wang, X.-D., A.-P. Wang, and Y.-P. Zou. 1996. An improved procedure for the isolation of nuclear DNA from leaves of wild grapevine dried with silica gel. Plant Mol. Biol. Rptr. 14:369-373.

Wapshere, A.J. and K.F. Helm. 1987. Phylloxera and Vitis: An experimentally testable coevolutionary hypothesis. Amer. J. Enol. Viticult. 38:216-222.

Zencirci, N., Z. Kaya, Y. Anikster, and W.T. Adams (eds.). 1998. Proc. Intl. Symp. on In Situ Conservation of Plant Genetic Diversity. Central Res. Inst. for Field Crops, Ankara, Turkey. 